\title{
A PHARMACOGNOSTIC AND PHARMACOLOGICAL REVIEW ON ALSTONIA SCHOLARIS
}

\author{
VANITA KANASE ${ }^{1 *}$, DEEPALI J MANE ${ }^{2}$
}

${ }^{1}$ Head, Department of Pharmacology, Oriental College of Pharmacy Sector 2, Sanpada, Navi Mumbai - 400 705, Maharashtra, India. ${ }^{2}$ Master of Pharmacy Student, Department of Pharmacology, Oriental College of Pharmacy Sector 2, Sanpada, Navi Mumbai - 400705, Maharashtra, India. Email: vanita.kanase@gmail.com

Received: 26 June 2018, Revised and Accepted: 28 July 2018

\begin{abstract}
Alstonia scholaris, commonly known as devil's tree, is an important medicinal plant in the various folk and traditional systems of medicine in Asia, Australia, and Africa. The plant is used in Ayurvedic, Unani, and Siddha types of alternative medicinal systems. The decoction, mostly prepared from the bark, is used to treat a variety of diseases, of which the most important is malaria. In Ayurveda, it is used as a bitter and as an astringent herb for treating skin disorders, malarial fever, urticaria, chronic dysentery, diarrhea, and in snake bite. A. scholaris is also observed to possess antioxidant, immunomodulatory effects, and free radical scavenging, anti-inflammatory, antimutagenic, anticancer, analgesic, hepatoprotective, wound healing, antidiarrheal, and antiplasmodial activities. The current review summarizes the numerous ethnobotanical and traditional uses as well as the phytochemical and pharmacological report on A. scholaris.
\end{abstract}

Keywords: Alstonia scholaris, Saptparni, Pharmacological study, Pharmacognostic study.

(C) 2018 The Authors. Published by Innovare Academic Sciences Pvt Ltd. This is an open access article under the CC BY license (http://creativecommons. org/licenses/by/4. 0/) DOI: http://dx.doi.org/10.22159/ajpcr.2018.v11i12.28124

\section{INTRODUCTION}

Alstonia scholaris also known as devil tree is an evergreen tree growing up to height of $100 \mathrm{~m}$. It is used against chronic diarrhea, dysentery, bowel movements, beriberi, congestion of liver, dropsy, and ulcers [1]. A. scholaris (L.) R.Br. (Apocynaceae) is an evergreen tropical tree native to Indian subcontinent and Southeast Asia, having grayish rough bark and milky sap rich in poisonous alkaloid. This plant is a native of India, Sri Lanka, Pakistan, Nepal, Thailand, Burma, Malaysia, Southeast Asia, Africa, Northern Australia, Solomon Islands, and Southern China [2-7].

The plant is a large, growing up to $17-20 \mathrm{~m}$ in height, with a straight often grooved and supported bole, about $110 \mathrm{~cm}$ in diameter. Bark is grayish-brown, rough, lenticellate abounding, bitter in taste secreting white milky latex. Leaves are 4-7 in a whorl, coriaceous, elliptic-oblong. Flowers are small, greenish-white, many in umbellate panicles, corolla tube is short, very strongly scented. Fruits have follicles, $30-60 \mathrm{~cm}$ long. Seeds are papillose with brownish hair at each end [3]. The bark, also called dita bark, is traditionally used by many ethnic groups of Northeast India and other parts of the world as a source cure against bacterial infection, malarial fever, toothache, rheumatism, snakebite, dysentery, bowel disorder, etc. Furthermore, the latex is used in treating coughs, sores, and fever $[3,8,9]$. It is a beautiful foliage tree with a large covering, and because of this, it has become a popular ornamental tree in the landscapes and gardens in the warm and moderate regions of Florida, Texas, and California in the United States [2].

A. scholaris (L.) R.Br. has been used in traditional systems of medicine for treating various diseases. Leaves of $A$. scholaris Linn. are known to contain very high amount of alkaloids (Ramchandra et al., 2012) which can be extracted for as source of natural fungicide [10]. The ripe fruits of the plant are used in syphilis and epilepsy. It is also used as a tonic, antiperiodic, and anthelmintic. The milky juice of A. scholaris (L.) R.Br. has been applied to treat ulcers. The bark is the most intensively used part of the plant and is used in many compound herbal formulas [3]. It is a bitter tonic, alternative, and febrifuge and is reported to be useful in the treatment of malaria, diarrhea, and dysentery $[3,6,7,11]$. Recently, the leaf extract has also been found to own antimicrobial properties [12]. A. scholaris (L.) R.Br. has also been reported to inhibit liver injuries induced by carbon tetrachloride, beta-d-galactosamine, acetaminophen, and ethanol as remarked by the reduced elevation of levels of serum transaminases and histopathologic changes such as cell necrosis and inflammatory cell infiltration [13]. Screening of natural products from plants provides the chance to discover new molecules of the unique structure with high activity and selectivity [14].

\section{MORPHOLOGICAL CHARACTERISTICS}

Saptaparna is a medium-sized evergreen tree, usually $12-18 \mathrm{~m}$ high, sometimes up to $27 \mathrm{~m}$ high. Bark is rough, grayish-white, yellowish inside, and exudes bitter latex when injured. Leaves are four-seven in a whorl, and are thick, oblong, with a blunt tip. They are dark green on the top, and pale and covered with brownish pubescence on the dorsal surface [15].

Habitat

A dominant canopy species found in coastal mesophyll vine forest with a canopy height of 35-42 m, in palm-dominated forests and in notophyll vine forests. Plant parts are shown in Fig. 1.

\section{Stem}

Bark yellowish and gray rough from inside, branches whorled, young branches lenticellate when the bark is injured a milky juice comes out.

\section{Leaves}

4-7 in whorls, coriaceous, oblong-lanceolate, obtuse or bluntly acuminate, dark green above, pale and covered with whitish bloom beneath, base tapering, main nerves numerous, nearly horizontal, parallel, uniting in an intramarginal nerve.

\section{Inflorescence}

Capitate cymes.

\section{Flowers}

- Small, fragrant, greenish-white, in umbellate, branched many - flowered, pubescent capitate cyme, peduncles $2.5-5 \mathrm{~cm}$ long, pedicels very short, bracts oblong, pubescent.

- Calyx $0.3 \mathrm{~cm}$, lobes oblong, obtuse, ciliate.

- Corolla tube $0.8 \mathrm{~cm}$ long, villous inside, mouth with ring of hairs, lobes 
cuneate oblong, rounded or subtruncate at the apex, pubescent. - Carpels pubescent.

Fruit

Follicles 30-60 cm long and $0.3 \mathrm{~cm}$ in diameter, cylindric, drooping in clusters, become completely averted after dehiscence.

Seeds

$0.6 \mathrm{~cm}$ long, linear-oblong, flat, round with fringe of hairs at both ends.

Flowering and fruiting time

December-March and May-July [16].

\section{CLIMATE AND SOIL}

Trees only flower after marked periods of dry weather. The species can be grown in a variety of climatic conditions in India, ranging from dry tropical to subtemperate. However, it blooms well in areas where annual rainfall is about $100-150 \mathrm{~cm}$, as it prefers a fairly moist habitat. The species grows well in the red alluvial soil having proper aeration. It can bloom in black cotton soils as well, but the growth is slow due to prevailing moist soil conditions during rainy season [15].

\section{INDIAN NAMES [19]}

Bengali: Chattim

Hindi: Saptaparni, Shaitankajhar, Chitvan

Kannada: AeleleHaale, Bantale, Doddapala

Malayalam: Daivappala

Marathi: Satvin

Sanskrit: Saptaparna

Tamil: Ezilaipillai, mukumpalai

Telugu: Daevasurippi

Gujrati: Satvana.

\section{TAXONOMICAL DISTRIBUTION [20]}

Kingdom: Plantae

Subkingdom: Viridiplantae

Infrakingdom: Streptophyata

Superdivision: Embryophyata

Division: Tracheophyata

Subdivision: Spermatophytina

Class: Magnoliopsida

Superorder: Asteranae

Order: Gentianales

Family: Apocynaceae

Tribe: Plumeriae

Subtribe: Alstoniinae

Genus: Alstonia

Species: A. scholaris.

\section{Synonyms}

Echites scholaris, Alstonia kurzii, Tabernaemontana alternifolia, Acokanthera scholaris, and Echitespala [21].

\section{Common names}

Indian pulai, white cheesewood, devil tree, blackboard tree, milkwood pine, dita bark, and bitter bark [21].

\section{CHEMICAL COMPOSITION}

The various species of Alstonia are highly rich in alkaloids, steroids, and triterpenoids, and phenolic compounds which contribute to the toxicity of $A$. scholaris [22]. Various alkaloids that have been reported in stem bark of $A$. scholaris includes alstonidine, O-methylmacralstonine, macralstonine 0 -acetylmacralstonine, alstonine, ditamine, echicaoutchin, corialstonidine, corialstonine chlorogenine, villalstonine, pleiocarpamine, macrocarpamine, and triterpenoids which have been reported are alpha-amyrin linoleate, lupeol palmitate, and lupeol linoleate $[23,24]$. There have been several other alkaloids that had been isolated and reported which are 12-methoxyechitamidine, 5-epinareline ethyl ether, nareline methyl ether, scholaricine, picrinine, and scholarine-N(4)oxide [25], 19-hyroxytubotaiwine [25], 6,7-seco-19,20epoxyyanggustibobine $\mathrm{B}$, Nb-methyl-scholarine, Na-metylburnamine, 19-epischolarine and vallesamineNb-oxide [27], 19,20-[E]-vallesamine, angustilobine, 20(S)-tubotaiwine, B-N4-oxide, and 6,7-secoangustilobine [28].

Leaves of $A$. scholaris have been the source of new picrinine - types of monoterpenoid indole alkaloids which are 5-methoxystrictamine, picralinal, and 5-methoxyaspidophylline [29]. Alkaloids such as ditamine, echitamine, and echitenine obtained from bark of $A$. scholaris are yellow-colored amorphous mass. Acicular crystals form of echicerin and crystallized scales of echitin have been reported from bark extract. Similar alkaloids such as echitein (a crystallizable acid) in rhombic prisms and an amorphous substance called echiretin are all like an alkaloid, a fatty acid and fatty resinous substances [30]. Ditain which is an uncrystallizable bitter principle was isolated long ago and attributed to have antipyretic properties. Ditamine and echitamine can be extracted with ether and chloroform by making the solution alkaline with sodium bicarbonate and $\mathrm{NaOH}$, respectively. Echitamine (C22H2504N2) is major alkaloidal constituent of several species of Alstonia such as A. angustiloba, A. gilletii, A. congensis, and A. spathulata including $A$. scholaris; however, the same alkaloid was absent in other species of Alstonia such as A. villosa, A. constricta, or A. macrophylla. Lupeol acetate, stigmasterol, and $\alpha$-sitosterol have been isolated from root bark [30]. Alkaloids such as chlorogenic acid and several other hallucinogenic indole alkaloids which have been reported in the seeds of $A$. scolaris are chlorogenine, alstovenine, reserpine, echitamine, ditamine, and venenatine. 7-megastigmene-3, 6, 9-triol and megastigmane-3 $\beta, 4 \alpha$, 9-triol are the two important structures which have been identified and were extracted from the leaves of $A$. scholaris and are known to be C13-norisoprenoids [31]. Alstonic acids such as 2, 3 -secofernane triterpenoids were also found to be isolated from leaves of A. scholaris [32] (Fig. 2).

\section{TRADITIONAL USES}

Bark

The bark of $A$. scholaris is useful in malarial fevers, abdominal disorders, dyspepsia, and in skin diseases [34]. The bark is bitter,

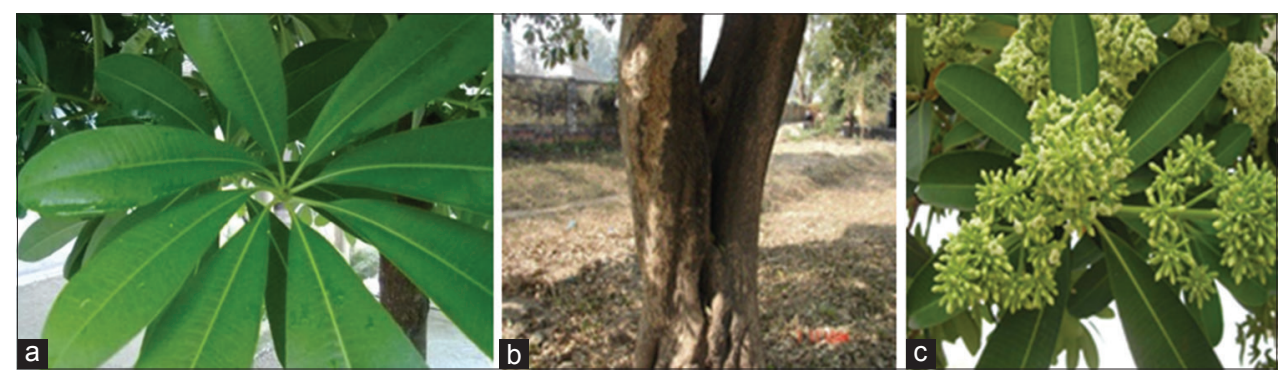

Fig. 1: (a) Leaves [17], (b) bark [18], (c) flowers [18] 


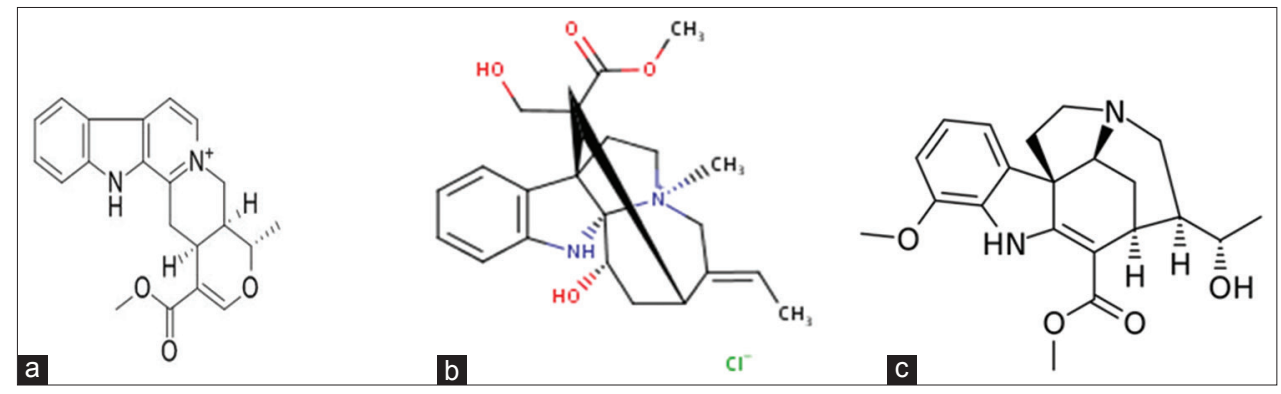

Fig. 2: (a) Alstonine; (b) echitamine; (c) scholarine

\section{PHYTOCHEMICAL SCREENING [33]}

Phytochemical constituents in various extracts are shown in Table 1.

Table 1: Phytochemical constituents in various extract

\begin{tabular}{|c|c|c|c|c|c|c|c|c|c|c|c|c|c|c|c|c|c|c|}
\hline \multirow[t]{2}{*}{ Compounds } & \multicolumn{6}{|c|}{ Leaves } & \multicolumn{6}{|c|}{ Stem bark } & \multicolumn{6}{|c|}{ Roots } \\
\hline & $\mathbf{H}$ & B & I & $\mathbf{E}$ & M & $\mathbf{W}$ & $\mathbf{H}$ & B & I & $\mathbf{E}$ & M & $\mathbf{W}$ & $\mathbf{H}$ & B & I & $\mathbf{E}$ & M & $\mathbf{W}$ \\
\hline Alkaloids & ++++ & ++++ & ++++ & ++++ & ++++ & ++++ & - & ++++ & ++++ & - & ++++ & ++ & - & - & +++ & ++ & +++ & ++++ \\
\hline Amino acid & - & - & - & - & - & - & - & - & - & - & - & ++ & - & - & - & - & - & - \\
\hline $\begin{array}{l}\text { Fixed oil and } \\
\text { fats }\end{array}$ & - & - & - & - & - & - & - & - & - & +++ & - & - & +++ & ++ & - & ++ & + & - \\
\hline $\begin{array}{l}\text { Phenolic } \\
\text { compounds }\end{array}$ & - & ++++ & - & - & ++++ & - & - & - & - & - & - & - & +++ & ++++ & ++ & - & ++ & - \\
\hline Terpenoids & - & - & +++ & +++ & - & ++ & ++++ & - & ++++ & ++++ & +++ & ++ & ++ & ++ & ++++ & + & +++ & ++++ \\
\hline $\begin{array}{l}\text { Cardiac } \\
\text { glycosides }\end{array}$ & - & - & - & - & - & - & - & +++ & - & - & - & - & - & - & - & - & - & - \\
\hline Steroids & ++++ & ++++ & ++++ & + & ++ & ++ & - & ++++ & ++++ & - & ++ & ++ & - & +++ & ++ & + & + & ++ \\
\hline Saponins & + & +++ & ++ & - & ++++ & ++++ & - & - & +++ & - & ++++ & ++++ & - & - & ++++ & +++ & ++++ & ++++ \\
\hline
\end{tabular}

Weak (+), moderate (++), strong (+++), very strong (++++), absent (-), H: Hexane extract, B: Benzene extract, I: Isopropanol extract, E: Ethyl acetate extract, M: Methanol extract, $\mathrm{W}$ : Water extract

astringent, digestive, laxative, anthelmintic, antipyretic, stomachic, cardiotonic, and tonic [35]. The bark extract has been reported to possess antiplasmodial, immunostimulant, and anticancer effect and is also hepatoprotective [36]. In Ayurveda, it is reported that the bark of the plant, when soaked in water overnight, can reduce the blood glucose level after oral administration [37]. Bark is also used as febrifuge, depurative, and galactagogue [38]. It is effective in leprosy, skin diseases, pruritis, chronic and foul ulcers, asthma, bronchitis, agalactia, and debility [35]. In folklore medicine, milky juice is applied on wounds, ulcers, and rheumatic pains; mixed with oil and dropped into ear, it relieves earache [38].

\section{Leaves}

The leaves have been used traditionally as folk remedies for the treatment of many diseases including diarrhea, dysentery, malaria, and snake bites [39]. Juice of the leaves acts in certain cases as a powerful galactagogue. Leaves used in beriberi, dropsy, and congested liver. Latex applied to sores, ulcers, tumors, and rheumatic swellings [38].

\section{Fruits}

The ripe fruits of the plant are used in syphilis and epilepsy. It is also used as a tonic, antiperiodic, and anthelmintic [40].

\section{PHARMACOLOGICAL ACTIVITIES}

\section{Anticancer activity}

Methanol extracts of root barks of A. macrophylla, A. glaucescens, and A. scholaris, collected from Thailand, have been assessed for cytotoxic activity against two human lung cancer cell lines, MOR-P (adenocarcinoma) and COR-L23 (large cell carcinoma), using the sulforhodamine B assay. Pleiocarpamine, 0-methyl macralstonine, and macralstonine were all considerably less active than villalstonine [41].

\section{Antidiabetic potential}

Several in vitro and in vivo studies were undertaken by researchers to evaluate traditional and local antidiabetic claim of $A$. scholaris. Antidiabetic potential of $A$. scholaris was studied in terms of its $\alpha$-glucosidase inhibitory and hypoglycemic effects $[42,43]$. To date, potent antidiabetic activity was reported to the leaves and stem bark of A. scholaris $[43,44]$. The powder of $A$. scholaris leaves exerts a consistent hypoglycemic effect in patients suffering from non-insulin-dependent diabetes mellitus. The hypoglycemic effect $A$. scholaris leaves powder in patients suffering from non-insulin-dependent diabetes mellitus was ascribed to their insulin triggering and direct insulin-like actions [45].

\section{Antidiarrheal activity}

The antidiarrheal effects of the aqueous and the alcoholic bark extracts of A. scholaris in mice were reported by Patil et al. [46].

\section{Antimicrobial activity}

Goyal et al. [47] reported the antimicrobial property of the plant constituents of A. scholaris (alkanes, alkanols, and sterols). Khan et al. [48] evaluated the antibacterial activity of the petrol, dichloromethane, ethyl acetate, and butanol fractions of crude methanolic extracts of the leaves, stem, and root barks of $A$. scholaris and reported that butanol fraction exhibited broad spectrum of antibacterial activity.

\section{Analgesic and anti-inflammatory activities}

The effect of ethanolic extract of leaves of $A$. scholaris was evaluated in experimental models of pain and inflammation [49]. The leaf extract at 200 and $400 \mathrm{mg} / \mathrm{kg}$ showed significant decrease in acetic acidinduced writhing in mice with a maximum of $65.76 \%$ at $400 \mathrm{mg} / \mathrm{kg}$. In hot plate method, the percentage of pain inhibition was found to be 
$73.90 \%$ and $79.56 \%$ with 200 and $400 \mathrm{mg} / \mathrm{kg}$ of extract. There was a significant inhibition in carrageenan-induced paw edema with 200 and $400 \mathrm{mg} / \mathrm{kg}$ of the extract.

\section{Antioxidant}

Antioxidants are the substances which counteract with the excess free radicals, reactive oxygen species, and nitric oxide; and nullified their pathological $[50,51]$. Plants are the excellent source of natural antioxidants which reduce the risk of certain diseases such as cancer, heart diseases, and stroke [51-53]. Thus far, antioxidant activity of $A$. scholaris has been studied within in vitro study models. There is no report on in vivo antioxidant potential of A. scholaris. James et al. [54] reported that the methanol extracts of flower had higher antioxidant activity than the fruit. The observed radical scavenging and antioxidant potential of potential of leaves were ascribed to its phenolic and flavonoid content, and of flower and fruit extracts to their flavonoid content $[55,56]$.

\section{Antiplasmodial activity}

Keawpradub et al. evaluated the antiplasmodial activity of the methanolic extracts of various parts of $A$. scholaris which was tested against multidrug-resistant K1 strain of Plasmodium falciparum cultured in 73 human erythrocytes. Pronounced antiplasmodial activity was exhibited. The indole alkaloids were isolated from the active extract and were subsequently tested against the K1 strain of $P$. falciparum. They reported pronounced antiplasmodial activity mainly among the bisindole alkaloids, particularly villalstonine and macrocarpamine with IC50 values of 0.27 and $0.36 \mu \mathrm{M}$, respectively [57]. Ironically Gandhi and Vinayak have reported that the petroleum ether extract and methanol extract of the bark of $A$. scholaris were found to be devoid of antimalarial activity in mice infected with Plasmodium berghei. However, they have noticed a dose-dependent improvement of conditions and delayed mortality among animals receiving methanol extract of $A$. scholaris [58]. Reports state that $A$. scholaris has little or no demonstrable action in malaria induced in monkeys and naturally occurring in human patients. It cannot, therefore, be recommended as a substitute for quinine and other cinchona alkaloids [59].

\section{Hepatoprotective activity}

The hepatoprotective effect of $A$. scholaris R. Br. on liver injuries induced by carbon tetrachloride $\left(\mathrm{CCl}_{4}\right)$, HD galactosamine, acetaminophen, and ethanol was investigated by Lin et al. by serum biochemical and histopathological examinations. All serological and histopathological effects of $A$. scholaris were comparative with those of Bupleurum chinense, which has been reported previously as treatment criteria of hepatitis. A tendency was also shown to inhibit cell necrosis and inflammatory cell infiltration caused by H-D galactosamine in histopathological examination [60].

\section{Immunomodulatory activity}

The immunostimulating effect of $A$. scholaris bark extracts was studied in BALB/c mouse by Iwo et al. [55]. The aqueous extract at $100 \mathrm{mg} / \mathrm{kg}$ b.w. increased lytic activity of peritoneal exudate cells against Escherichia coli. At the doses of 50 and $100 \mathrm{mg} / \mathrm{kg}$ b.w., the aqueous extract had no effect on primary antibody level. The aqueous extract at $50 \mathrm{mg} / \mathrm{kg}$ b.w. induced the cellular immune response while at $100 \mathrm{mg} / \mathrm{kg}$ b.w. inhibited the delayed type of hypersensitivity reaction [61].

\section{Molluscicidal and anticholinesterase activity}

The aqueous extract of stem barked leaf of drug has molluscicidal as well as in vivo and in vitro anticholinesterase activity against the snail Lymnaea acuminata. The aqueous stem bark extract shows strong molluscicidal activity in comparison to leaf at all exposure periods in time as well as dose-dependent manner (LC50 value decreases from 665.82 to $138.32 \mathrm{mg} / \mathrm{L})$.The anticholinesterase activity is also dose dependent [62].

\section{CONCLUSION}

A. scholaris is very useful plant for treating the various types of diseases. Various types of studies done on plant such as antioxidant, anticancer, antidiarrheal, antimicrobial, antiplasmodial, analgesic and anti-inflammatory, immunomodulatory, hepatoprotective, and wound healing activity. This review concluded that $A$. scholaris considers to be useful medicinal plant in future.

\section{ACKNOWLEDGMENT}

We are very grateful to our Principal Dr. (Mrs.) Sudha Rathod, Prof. Imtiyaz Ansari for their guidance and support as well as to Pharmacology Department, Oriental College Pharmacy, Navi Mumbai.

\section{AUTHORS' CONTRIBUTION}

We declare that this work was done by the authors named in this article and all liabilities pertaining to claims relating to the content of this article will be borne by the authors. Miss. Deepali Mane collected the data and analyzed the data Dr. Mrs. Vanita Kanase proofread the whole manuscript, and suggested the necessary changes, and helped in designing manuscript.

\section{CONFLICTS OF INTEREST}

The authors declare that there are no conflicts of interest regarding the publication of this paper.

\section{REFERENCES}

1. Nadkarni AK, Nadkarni KM. Indian Materia Medica. Vol. I. Bombay: Popular Prakashan; 1976. p. 80-3.

2. Anonymous. The Wealth of India: Raw Materials. Vol. 43. New Delhi, India: Council of Scientific and Industrial Research; 1960

3. Nadkarni AK. Indian Materia Medica. $3^{\text {rd }}$ ed. Mumbai, India: Popular Press; 1976.

4. Kirtikar KR, Basu BD. Indian Medicinal Plants. Vol. 2. Dehradun, India: Bhushen Singh Mahendra Pal Singh; 1935.

5. Sathyavathi GV, Gupta AK, Tandon N. Medicinal Plants of India. Vol. 2. New Delhi, India: Indian Council of Medical Research; 1987. p. 230-9.

6. Warrier PK, Nambiar VP, Ramankutty C. Indian Medicinal Plants. Hyderabad, India: Orient Longman; 1996.

7. Chemexcil. Selected Medicinal Plants of India. Bombay, India: Basic Chemicals, Pharmaceutical and Cosmetic Export Promotion Council; 1992. p. 205-7.

8. Bhattacharjee SK. Handbooks on Medicinal Plant. $4^{\text {th }}$ Rev Edition. Jaipur, India: Pointer Publishers; 2004.

9. Kumar S. Medicinal Plants of North-East Region. $1^{\text {st }}$ ed. Rajasthan, India: Scientific Publishers; 2002.

10. Ramchandra YL, Sudeep HV, Rai P, Ramdas K. Evaluation of wound healing activity of leaf extract of Alstonia scholaris Linn. in rats. Int $\mathbf{J}$ Pharm Pharm Sci 2012;1 Suppl:390-3.

11. Sathyavathi GV, Gupta AK, Tandon N. Medicinal Plants of India. Vol. 2. New Delhi, India: Indian Council of Medical Research; 1987. p. 2309.

12. Omoregbe RE, Ikuebe OM, Ihimire IG. Antimicrobial activity of some medicinal plants extracts on Escherichia coli, Salmonella paratyphi and Shigella dysenteriae. Afr J Med Med Sci 1996;25:373-5.

13. Lin SC, Lin CC, Lin YH, Supriyatna SS, Pan SL. The protective effect of Alstonia scholaris R.Br. on hepatotoxin-induced acute liver damage. Am J Clin Med 1996;24:153-64.

14. Tilak R, Kumar P, Rathee R, Dubey KK. Screening of some medicinal plants for their antimicrobial activities. Int $\mathrm{J}$ Pharm Pharm Sci 2016;8:202-6

15. Available from: http://www.vikaspedia.in/agriculture/crop-production/ package-of....and../alstonia-scholaris.

16. Available from: http://www.efloraofgandhinagar.in/tree/alstoniascholaris.

17. Dey A. Alstonia scholaris R.Br.(Apocynaceae): Phytochemistry and pharmacology: A concise review. J Appl Phram Sci 2011;1:51-7.

18. Pankti K, Payal G, Manodeep C, Jagadish K. A phytopharmacological review of Alstonia scholaris: A panoramic herbal medicine. Int J Res Ayurveda Pharm 2012;3:367-7.

19. Abhijit D. Alstonia scholaris R.Br. (Apocynaceae): Phytochemistry and pharmacology: A concise review. J Appl Pharm Sci 2011;1:51-7.

20. Available from: https://www.itis.gov/servlet/SingleRpt/SingleRpt?search_ topic $=$ TSN\&search value $=184803 \#$ null

21. Available from: https://florafaunaweb.nparks.gov.sg/special-pages/ 
plant-detail.aspx?id=2705.

22. Singh SK, Singh A. Molluscicidal and anti-cholinesterase activity of Alstonia scholaris plant against freshwater snail Lymnaea acuminata. Pak J Biol Sci 2003;6:1442-6.

23. Baliga MS, Jagetia GC, Ulloor JN, Baliga MP, Venkatesh P, Reddy R, et al. The evaluation of the acute toxicity and long term safety of hydroalcoholic extract of sapthaparna (Alstonia scholaris) in mice and rats. Toxicol Lett 2004;151:317-26.

24. Jagetia GC, Baliga MS, Venkatesh P. Effect of sapthaparna (Alstonia scholaris linn) in modulating the benzo(a)pyrene-induced forestomach carcinogenesis in mice. Toxicol Lett 2003;144:183-93.

25. Banerji A, Siddhanta AK. Scholarine: An indole alkaloid of Alstonia scholaris. Phytochemistry 1981;20:540-2.

26. Yamauchi T, Abe F, Chen RF, Nonaka GI, Santisuki T, Padolina WG. Alkaloids from the leaves of Alstonia scholaris in Taiwan, Thailand, Indonesia and Philippines. Phytochemistry 1990;29:3547-52.

27. Yamauchi T, Abe F, Padolina WG, Dayrit FM. Alkaloids from leaves and bark of Alstonia scholaris in the Philippines. Phytochemistry 1990;29:3321-5.

28. Jagetia GC, Baliga MS. The effect of seasonal variation on the antineoplastic activity of Alstonia scholaris R. Br. In heLa cells. J Ethnopharmacol 2005;96:37-42.

29. Cai XH, Liu YP, Feng T, Luo XD. Picrinine-type alkaloids from the leaves of Alstonia scholaris. Chinese J Natl Med 2008;1:20-2.

30. Singh MP, Panda H. Medicinal Herbs with Their Formulations. New Delhi: Daya Publishing House; 2005. p. 88-90.

31. Yan XU, Feng T, Cai XH, Luo XD. A new C13-Norisoprenoid from leaves of Alstonia scholaris. Chinese J Natl Med 2009;1:21-3.

32. Wang F, Ren FC, Liu JK. Alstonic acids A and B, unusual 2,3-secofernane triterpenoids from Alstonia scholaris. Phytochemistry 2009;70:650-4.

33. Misra KP, Maurya R, Srimal RC, Yadav VS, Pandey R, Mehrotra S, et al. A comparative study on screening and antibacterial activity of roots of Alstonia scholaris with the roots, leaves, stem bark. Int J Res Phytochem Pharmacol 2011;1:77-82.

34. Kirtikar KR, Basu BD. Indian Medicinal Plants. Vol. 2. Dehradun: International Book Distributors; 1999.

35. Nadkarni AK. Indian Materia Medica. Vol. 1. Mumbai: Bombay Popular Prakashan; 1976.

36. Lin SC, Lin CC, Linn YH, Supriyatna S, Pal SL. The protective effect of Alstonia scholaris R.Br. On hepatotoxin induced acute liver damage. Am J Clin Med 1996;24:153-64.

37. Deepti B, Archana J, Manasi J. Antidiabetic and antihyperlipidemic effect of Alstonia scholaris Linn bark in streptozotocin induced diabetic rats. Ind J Pharm Edu Res 2011;45:114-20.

38. Arulmozhi S, Mazumder PM, Narayan LS, Thakurdesai PA. In vitro antioxidant and free radical scavenging activity of fractions from Alstonia scholaris Linn R. Br Int J Pharm Tech Res 2010;2:18-25.

39. Kirtikar KR, Basu BD. Indian Medicinal Plants. Vol. 1. Allahabad: LM Basu Publication; 1935.

40. Pawan K, Dhirender K, Neha S, Rana S. Alstonia scholaris: It's phytochemistry and pharmacology. Chron Young Sci 2011;2:71-8.

41. Keawpradub N, Houghton PJ, Eno-Amooquaye E, Burke PJ. Activity of extracts and alkaloids of Thai Alstonia species against human lung cancer cell lines. Planta Med 1997;63:97-101.
42. Anurakkun NJ, Bhandari MR, Kawabata J. $\alpha$-glucosidaseinhibitorsfrom devil tree (Alstonia scholaris). Food Chem 2007;103:1319-23.

43. Arulmozhi S, Mazumder PM, Lohidasan S, Thakurdesai P. Antidiabetic and antihyperlipidemic activity of leaves of Alstonia scholaris Linn. R. Br. Eur J Integr Med 2010b;2:23-32.

44. Bandawane D, Juvekar A, Juvekar M. Antidiabetic and antihyperlipidemic effect of Alstonia scholaris Linn. Bark in streptozotocin induced diabeticrats. Indian $\mathrm{J}$ Pharm Educ Res 2011;45:114-20.

45. Akhtar MS, Bano H. Hypoglycemic effect of powdered Alstonia scholaris (Satona). Prof Med J 2002;9:268-71.

46. Patil RS, Juvekar AR, Joglekar SN, Shamkuwar PB, Nimbkar SR. Study of antidiarrhoeal activity of Alstonia scholaris bark. Indian Drugs 1999;36:463-5.

47. Goyal MM, Varshney A. Effects of natural products isolated from three species of Alstonia on some gram-positive and gram-negative bacteria. Indian Drugs 1995;32:69-72.

48. Khan MR, Omoloso AD, Kihara M. Antibacterial activity of Alstonia scholaris and Leea tetramera. Fitoterpia 2003;74:736-40.

49. Arulmozhi S, Mazumder PM, Ashok P, Narayanan LS. Antinociceptive and anti-inflammatory activities of Alstonia scholaris Linn. R.Br. Pharmacog Mag 2007;3. (In Press).

50. Sies H. Antioxidants in Disease, Mechanisms and Therapy. New York: Academic Press; 1996.

51. Kasote DM. Flaxseed phenolics as natural antioxidants: A review. Int Food Res J 2013;20:1797-804.

52. Prior RL, Cao G. Antioxidant phytochemicals in fruits and vegetables: Dietand health implications. Hortic Sci 2000;35:588-92.

53. Rice-Evans C. Flavonoids and isoflavones: absorption, metabolism andbioactivity. Free Radic Biol Med 2004;36:827-8

54. James J, Veettil AK, Kumar P, Misra CS, Dev MS, Thankamani V. In vitro antioxidant activity of flowers and fruits of Alstonia scholaris. Int J Phytomed 2011;3:475-9.

55. Kumar A, Kaur R, Arora S. Free radical scavenging potential of some Indian medicinal plants. J Med Plants Res 2010;4:2034-42.

56. Shankar KR, Ramesh KV, Naveena P. Free radical scavenging activity of the flower and fruit extracts of Alstonia scholaris. Biosci Biotechnol Res Asia 2008;5:493-4.

57. Keawpradub N, Kirby GC, Steele JC, Houghton PJ. Antiplasmodial activity of extracts and alkaloids of three Alstonia species from Thailand. Planta Med 1999;65:690-4.

58. Gandhi M, Vinayak VK. Preliminary evaluation of extracts of Alstonia scholaris bark for in vivo antimalarial activity in mice. J Ethnopharmacol 1990;29:51-7.

59. Nadkarni AK. K.M. Nadkarni's Indian Materia Medica. Vol. I. Bombay: Popular Prakashan; 1976. p. 80-3.

60. Lin SC, Lin CC, Lin YH, Supriyatna S, Pan SL. The protective effect of Alstonia scholaris R.Br. On hepatotoxin-induced acute liver damage. Am J Clin Med 1996;24:153-64.

61. Iwo MI, Soemardji AA, Retnoningrum DS, Sukrasno UM. Immunostimulating effect of pule (Alstonia scholaris L. R.Br., Apocynaceae) bark extracts. Clin Hemorheol Microcirc 2000;23:177-83.

62. Sharma P, Sharma R, Rao HS, Kumar D. Phytochemistry and medicinal attributes of $A$. scholaris: A review. Int J Pharm Sci Res 2015;6:505-13. 